January 2010

\title{
The global pediatrician: is there such a person, or can there be?
}

Robert Armstrong

Aga Khan University, robert.armstrong@aku.edu

Follow this and additional works at: http://ecommons.aku.edu/ eastafrica_fhs_mc_paediatr_child_health

Part of the Pediatrics Commons

\section{Recommended Citation}

Armstrong, R. (2010). The global pediatrician: is there such a person, or can there be?. Journal of Paediatrics, 156(4), 517-518. Available at: http://ecommons.aku.edu/eastafrica_fhs_mc_paediatr_child_health/57 


\title{
The Global Pediatrician: Is There Such a Person, or Can There Be?
}

\author{
Robert W. Armstrong, MD, PhD, FRCPC
}

s pediatricians, our concern for the health of children and youth starts with our individual encounters with patients and their families and extends to the community in which they live and the broader systems of society that influence their health. This concept of a pediatrician is captured in one of the "bibles" of our profession and in the words of Richard Behrman when he defines pediatrics as being "concerned with the health of infants, children, and adolescents, their growth and development, and their opportunity to achieve full potential as adults." "Health, growth and development, and opportunity as adults encompass the breadth and importance of our interests and responsibilities.

Many institutions training our future pediatricians interpret this responsibility as not only encompassing the children in their community, but also expanding to a global concern for the health of children and youth. Indeed, many medical students and residents are encouraging faculty to pay more attention to global child health, and we are responding by creating more informal and formal opportunities for trainees to engage in global health issues. ${ }^{2,3}$ Our academic societies also have devoted more time to the issues of global child health and how we might more effectively contribute to this agenda, for example, the Federation of Pediatric Organizations, ${ }^{4}$ the International Pediatric Association (http://www.ipa-world. org), and the International Pediatric Academic Leaders Association (http://www.academicpediatrics.org).

If we are to have training programs for this "global pediatrician," what should the core elements of the curriculum look like? Can we begin to integrate these core elements into our training programs in a way that builds a common vision of the global pediatrician while also recognizing the distinct nature of practice in various communities?

We might first define a global pediatrician as a pediatrician who understands the state of child health locally and globally and has the knowledge, skills, attitudes, and behaviors necessary to improve the lives of children individually and in the world community. The pediatrician will have the knowledge and skills to diagnose and treat the diseases and disorders of childhood, both those common globally and those unique to their region. In addition, either directly through individual effort or indirectly through the support of engaged professional organizations, the global pediatrician will gain through training and will sustain through professional development a knowledge base that includes the following elements.

\section{Convention on the Rights of the Child}

The United Nations' Convention on the Rights of the Child ${ }^{5}$ is the most important document framing the position of children in the global community. The global pediatrician should understood and use this document as an advocacy tool and as a measure of a society's commitment to their children. No matter where or how we work as pediatricians, the near-universal endorsement of the Convention provides powerful language and a basis for our advocacy. There are increasing efforts to provide practicing professionals with the knowledge, tools, and strategies to effectively promote the principles of the Convention. ${ }^{6}$

\section{Population-Based Child Health Information}

Population-based information about children and their health and social status is an essential resource for the global pediatrician. The pediatrician must be able to access and integrate information from authoritative sources to address key questions of importance. In addition to standard information on mortality and disease occurrence, we now have an increasing capacity to map important demographic, health, and social information at the community, nation, and global levels. The information necessary to remain current and knowledgeable about the state of the world's children can be gained from reports such as those produced by United Nations Children's Fund. ${ }^{7}$ Understanding, having access to, and knowing how to use information about child health must be core elements of any training program aimed at producing a global pediatrician. When a resident admits a child to hospital with sepsis, he or she not only should understand the mechanisms, diagnosis, and treatment of sepsis, but also should be able to describe the importance of this disease to the health of children globally and understand appropriate strategies for addressing this problem at a population level.

\section{Child Development}

Fundamental to our role as pediatricians is our understanding of the processes of child development, the biological and environmental influences that affect successful development, and the importance of global initiatives to improve outcomes across different communities. A chapter in the World Health Organization's Commission on the Social Determinants of Health $^{8}$ is devoted to the importance of early child development and education as powerful forces in addressing

From the Department of Pediatrics, University of British Columbia, British Columbia Children's Hospital, Provincial Health Services Authority, Vancouver, BC, Canada.

0022-3476/\$ - see front matter. Copyright $\odot 2010$ Mosby Inc.

All rights reserved. 10.1016/j.jpeds.2010.01.001 
inequities in children's developmental outcomes. We have increasing access to globally available, population-based measures of development that capture important periods in the life of children and serve to focus attention on those systems that support healthy development. For example, the Early Development Index, which captures the proportion of children who are developmentally ready to succeed in school, is being used regionally and nationally in several countries. ${ }^{9}$ As we teach child development and see children with developmental problems in our clinic, we also should be aware of and interested in the global issues related to child development, such as detailed in the important Lancet series that estimated that more than 200 million children in the developing world are not meeting their developmental potential. ${ }^{10} \mathrm{~A}$ broad perspective on factors influencing the healthy development of children should be common across a global community of pediatricians.

\section{Global Goals Impacting Children}

The Millennium Development Goals were established by the United Nations as achievable targets for the global community to reach by $2015 .{ }^{11}$ Many of the goals that have been set (eg, elimination of poverty, universal education, child health, maternal health) relate directly to children and youth, and there is a very active world community working toward and monitoring the achievement of these goals. ${ }^{12}$ Global goals will be intermittently set by such world bodies, and the global pediatrician should understand these goals and the actions required to meet the goals, and also be actively engaged in helping set the goals themselves.

\section{Children in the Health Care System}

The global pediatrician will have an understanding of the range of health care systems that exist worldwide and the impact of these systems on issues of access and the quality of care that children will receive. There are enormous gaps in care for children and there is opportunity to examine and understand how different models of care can achieve better outcomes for children.

\section{Classification}

As clinicians, we are familiar with the International Classification of Diseases for describing the diseases and disorders of childhood because all countries use this system of classification. As pediatricians, we need to understand the value and power of collecting this data. Equally important is the evolving International Classification of Function, which not only encompasses impairment, but also classifies activities and participation of the child. ${ }^{13}$ These classification systems are intended to be universal in their design, and the global pediatrician will have a good understanding of their applications and limitations, while using them as a common tool of communication.

There is enormous variability in the manner in which pediatricians from different societies and nations of the world address Behrman's expectations for supporting the lives of children and youth. ${ }^{1}$ Beyond their individual encounters with children and families, pediatricians have an important role to play in global child heath. Therefore, we should include content in our training programs and in continuing professional education that advances our understanding of global child and youth health and gives us the tools to be more effectively engaged. It is encouraging to see our trainees, our practicing pediatricians, and our professional societies focus on global child health issues. Increasingly, the answer to the questions of whether there should be and can be a global pediatrician is a definitive "yes."

Reprint requests: Robert W. Armstrong, MD, PhD, FRCPC, Department of Pediatrics, University of British Columbia, British Columbia Children's Hospital, Provincial Health Services Authority, 4480 Oak Street, Vancouver, BC, Canada V6H 3V4. E-mail: barmstrong@cw.bc.ca.

\section{References}

1. Behrman R. Overview of pediatrics. In: Behrman RE, Kliegman RM, Jenson HB, editors. Nelson Textbook of Pediatrics. 17th ed. Philadelphia: WB Saunders; 2007.

2. Kamat D, Armstrong RW. Global child health: an essential component of residency training. J Pediatr 2006;149:735-6.

3. Nelson BD, Lee AC, Newby PK, Chamberlin MR, Huang C- C. Global health training in pediatric residency programs. Pediatrics 2008;122:28-33.

4. Sectish TC, Bartholomew JM, Slaw KM. The Federation of Pediatric Organizations strategic plan: six strategic initiatives to enhance child health. J Pediatr 2008;152:745-6.

5. Office of the United Nations High Commissioner for Human Rights. Convention on the Rights of the Child. Available from: http://www2. ohchr.org/english/law/crc.htm. Accessed January 31, 2010.

6. International Institute for Child Rights and Development. Child rights education for professionals. Available from: http://web.uvic.ca/iicrd/ CRED-PRO\%20Brochure.pdf. Accessed January 31, 2010.

7. UNICEF. State of the world's children 2009. Available from: http://www. unicef.org/sowc09/. Accessed January 31, 2010.

8. World Health Organization. Commission on Social Determinants of Health. Closing the gap in a generation. Final report. Geneva: World Health Organization; 2008.

9. Human Early Learning Partnership. Early Development Instrument. Available from: http://www.earlylearning.ubc.ca/EDI/. Accessed January 31, 2010 .

10. Grantham-McGregor S, Cheung YB, Cueto S, Glewwe P, Richter L, Strupp B. Developmental potential in the first 5 years for children in developing countries. Lancet 2007;369:60-70.

11. United Nations. End Poverty 2015: Millennium Development Goals. Available from: http://www.un.org/millenniumgoals/. Accessed January $31,2010$.

12. The 2008 Countdown to 2015 Working Group. Countdown to 2015 for maternal, newborn and child health: the 2008 report. Available from: http://www.countdown2015mnch.org. Accessed January 31, 2010.

13. World Health Organization. International Classification of Functioning, Disability and Health (ICF). Available from: http://www.who.int/ classifications/icf/en/. Accessed January 31, 2010. 